\title{
CERAMIC MEMBRANES IN INDIVIDUAL FIELD WATER TREATMENT
}

\author{
A. V. Kuzminichuk*, I. M. Astrelin, G. V. Krimets \\ ${ }^{1}$ National Technical University of Ukraine «Igor Sikorsky Kyiv Polytechnic Institute», \\ Kyiv, Ukraine \\ *e-mail: kuzminchuk.a@gmail.com
}

The article describes the production of filter elements for individual use. The methods and results of research on the synthesis of filter ceramics are described and the effect of various additives to raw mixes is analyzed.

Keywords: diatomaceous earth, kaolin, thermal analysis, ceramic membranes, water treatment.

\section{Introduction}

The technology of filtering ceramics has been actively developed in the last decade. Ceramic membranes have become quite widely used in wastewater treatment technologies and cost-effective water treatment technologies. In particular, in the market of sewage treatment materials of different origin, ceramic membranes confidently occupy the second position.

The largest manufacturers of filter ceramics are currently Pall Corporation (USA), TAMI Industries (France), Ateh Innovations (Germany), GEA Group (Germany), Veolia Water Technologies (France), ITN Nanovation (Germany), Hyflux Ltd. (Singapore), Jiangsu Jiuwu Hi-Tech Co., Ltd. Ltd. (China). The production of this ceramic in the Pacific Asia (China, South Korea) prevails.

As the main raw material base of filtering ceramics in the world practice are used natural materials: diatomite (organogenic mineral), kaolin (clay mineral) from local deposits, for example, Kolubara deposit in Serbia (Kayvani, 2018), production of diatomite Celatom in Italy (Farrelly, 2008), etc.) and imported ones. Sometimes diatomite used in the processing (brewery and other industries) is involved in processing (Mogollón-Cuellar, 2018).

Various compounds are used as additives to primary raw material mixtures in the preparation of filter ceramics: starch, barium sulfate, borax, liquid glass, etc. There are significant differences in the interpretation of the research.

The aim is to study the mode of ceramic filtering elements synthesis based on Ukrainian and imported raw materials (diatomaceous earth and kaolin) with another components and determination their structural characteristics and filtration efficiency.

\section{Experimental}

In the preparation of the raw material mixture used treated diatomite Celatom (USA) containing $89,5 \% \mathrm{SiO}_{2}, 4,1 \% \mathrm{Al}_{2} \mathrm{O}_{3}, 1,5 \% \mathrm{Fe}_{2} \mathrm{O}_{3}, 0,6 \% \mathrm{CaO}, 0,3 \% \mathrm{MgO}$ and $4 \%$ other oxides and kaolin of Hlukhovets deposit (Ukraine) with a content of approx 47\% SiO-2-, 38\% $\mathrm{Al}_{-2} \mathrm{O}_{3}$ and additives of $\mathrm{TiO}_{-2}, \mathrm{Fe}_{2} \mathrm{O}_{3}, \mathrm{MgO}$.

According to literature data (Farrelly, 2008, Kayvani, 2018, Mogollón- Cuellar, 2018, Saponjic, 2015), sodium tetraborate (borax), starch, manganese oxide $\mathrm{MnO}_{2}$, barium sulfate $\mathrm{BaSO}_{4}, \mathrm{CuSO}_{4}$ sulphate, $\mathrm{K}_{2} \mathrm{CO}_{3}$ potash or calcined soda $\mathrm{Na}_{2} \mathrm{CO}_{3}$ were selected as additives of the raw material mixture. The samples used in the experiments contained 52-55\% diatomite, 27-30\% kaolin, 5-6\% borax, 1-2\% starch, 3-4\% potash, 7-8\% $\mathrm{BaSO}_{4}, 1-1.5 \% \mathrm{MnO}_{2}, 0.5 \% \mathrm{CuSO}_{4}$ (in terms of dry components). The remaining elements, due to their low content, have no significant effect on the mechanical and filtering qualities.

All component ratios were selected experimentally. Table 1 shows the ranges of the percentage of different components in the mixture, using which you can get a product of satisfactory quality. 
Table 1. Component Content

\begin{tabular}{|c|c|}
\hline Component & Content, \% \\
\hline Diatomaceous earth & $50-70 \%$ \\
\hline Kaolin & $25-35 \%$ \\
\hline Starch & $0,5-2 \%$ \\
\hline $\mathrm{MnO}_{2}$ & $0,5-1,5$ \\
\hline Borax & $4-8$ \\
\hline $\mathrm{BaSO}_{4}$ & $7-12$ \\
\hline $\mathrm{CuSO}_{4}$ & $0,2-1$ \\
\hline $\mathrm{K}_{2} \mathrm{CO}_{3}$ or Na & $\mathrm{CO}_{3}$ \\
\hline
\end{tabular}

The preparation of the dry mixture included pre-grinding of the ingredients and thorough homogenization to achieve a uniform distribution of particles of all components in the volume. Mixing was carried out in a mortar

In the next step, liquid components were introduced into the dry mixture: water, electrolyte solutions, and impurity suspensions. Stirring was also performed manually.

In these investigations we used casting slurry in plaster form as the most rational, energy- and laborsaving method. This method allows to obtain both flat disks with an output of not less than $90 \%$ and cylindrical closed-end cylindrical elements with an output of $30-40 \%$.

Subsequent drying operation at temperatures of $378-423 \mathrm{~K}$ was carried out in order to remove the physical moisture from the semi-finished product. The duration of drying was determined by the thickness of the sample and generally did not exceed 3 hours.

Among the known methods of forming (Vitaly Gitis, Gadi Rothenberg, 2016) of the material obtained: pressing the dry or moist mixture under a pressure of ten to $100 \mathrm{MPa}$, extrusion of the semidry mass through the holes of the extruder with subsequent sealing by physical methods, the application of the molding mass on metal mesh, pottery molding, molding vacuum removal of moisture.

The final step of obtaining a ceramic filter element is the sintering of the dried mass.

Reasoned choice of sintering temperature regime carried out on the basis of diatomite thermal analysis and samples dried mixtures.

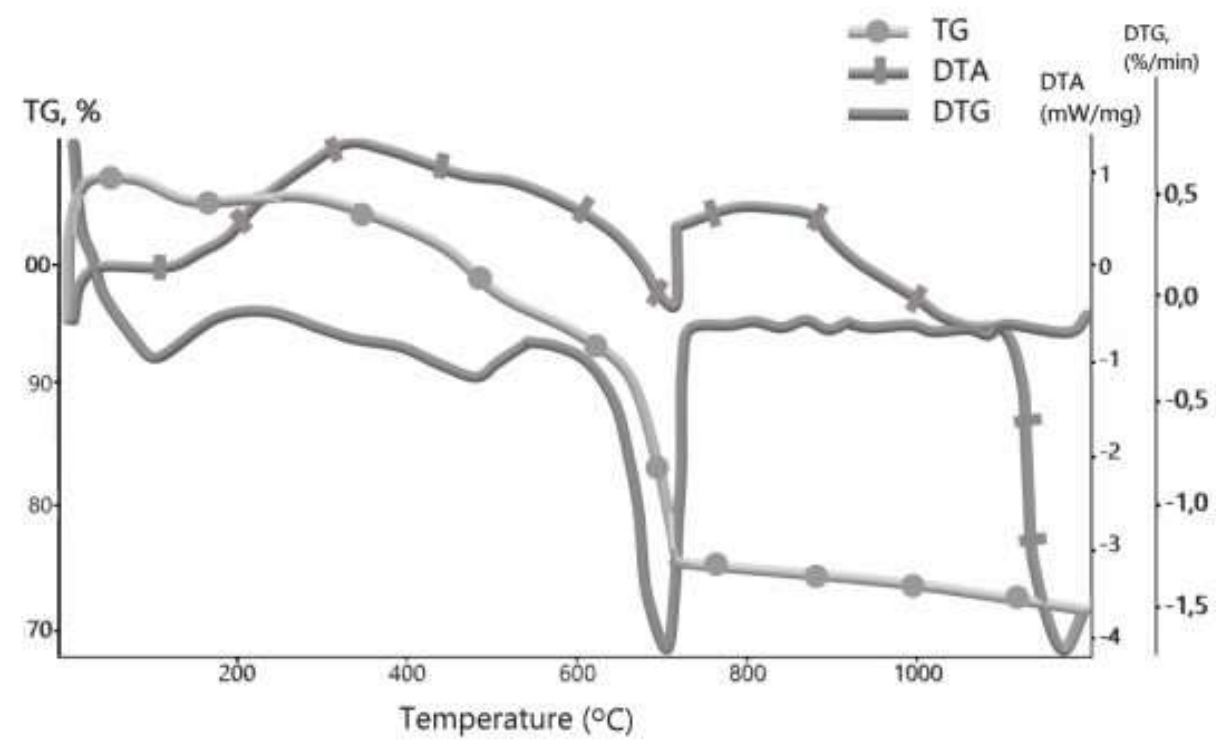

Fig. 1. Thermal analysis of natural diatomite sample.

As a result of diatomaceous earth thermal analysis (Ibrahim, 2012), the endothermic effect of evaporation of physically adsorbed water $(373-473 \mathrm{~K}$, loss of $0.7 \%$ of mass), endothermic effect at temperatures of $523-873 \mathrm{~K}$, associated with the removal of chemical moisture $(5.5 \%$ of mass loss) 
are recorded. Further endothermic effect $(873-1023 \mathrm{~K})$ shows the destruction of calcite in the composition (loss of $8.95 \%$ by weight).

Endothermic effect in the temperature range $1173-1473 \mathrm{~K}$ (with a loss of $1.73 \%$ by weight) reflects the full diatomite structure dehydration and the formation of new silica material. At temperatures up to $1273 \mathrm{~K}$, the formation of proper microporous structure does not occur (only 60-70\% porosity).

Figure 2 shows an analysis of a mixture of one of the best samples of the dried mixture, the composition is $52 \%$ diatomite, $27 \%$ kaolin, $6 \%$ borax, $2 \%$ starch, $3 \%$ potash, $8 \% \mathrm{BaSO}_{4}, 1.5 \% \mathrm{MnO}_{2}$, $0.5 \% \mathrm{CuSO}_{4}$ (in terms of dry components).

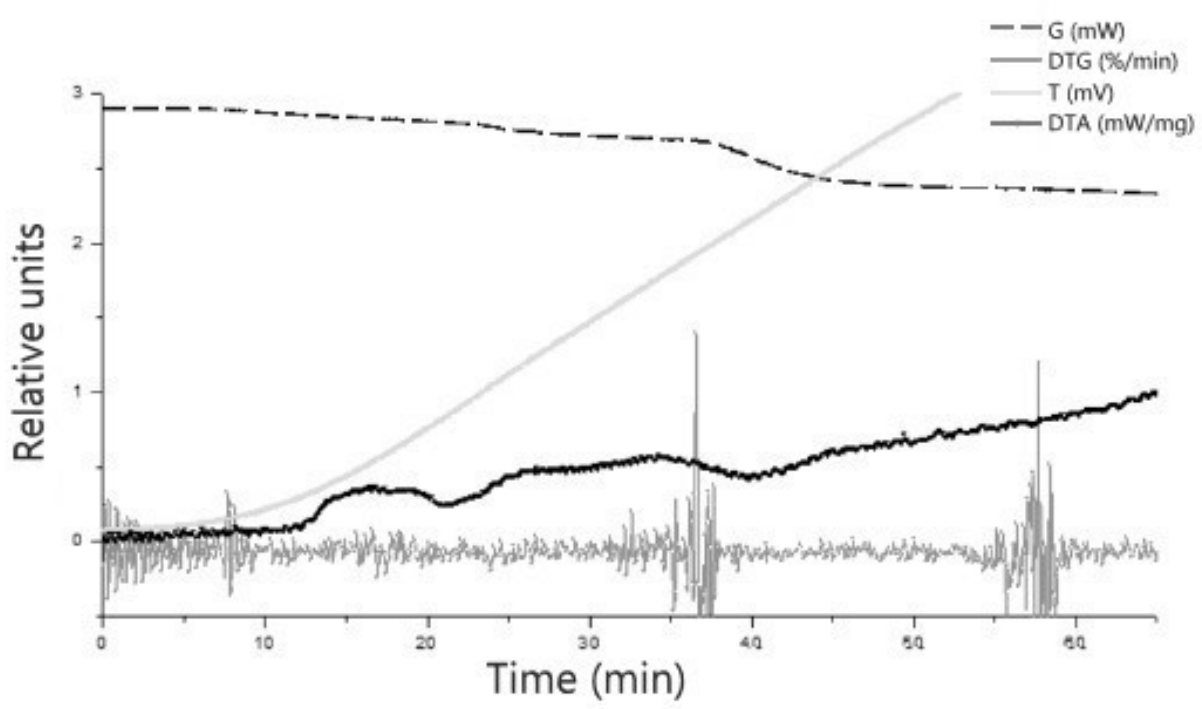

Fig. 2. Thermal analysis of the mixture sample.

Heat treatment of the dried mixture is accompanied by the effects of starch gelatinization in 383 393 K (Shiotsubo, Takahashi, 1984), dehydration of sodium tetraborate decahydrate (beginning at temperatures 413-433 K, termination at $653-673 \mathrm{~K}$ ), starch destruction (573 - $673 \mathrm{~K}$ ) (Qiu,2016), kaolinite dehydration with the formation of metakaolin $(786-923 \mathrm{~K})$ (Breck, 1983), phase transition from $\beta$ - to $\gamma$-modification of sodium tetraborate $(973-983 \mathrm{~K})$. It is noted that in the temperature range up to $1273 \mathrm{~K}$ there is no significant interaction between the basic components of the mixture, and only their individual thermal transformations are available.

The results of the thermal analysis of the mixture indicate a relationship with the conclusions obtained during the heat treatment of diatomaceous earth, namely: only at temperatures above $1273 \mathrm{~K}$ (up to $1473 \mathrm{~K}$ ) acceptable porosity with a mean pore diameter at the level above $50-55 \mathrm{~nm}$ is consistently formed in the material.

It has been experimentally proved that in addition to the charge of sodium tetraborate, there is no critical need for the glassing action, since sufficient mechanical properties of ceramic elements are ensured without its addition. More boron compounds reduce the porosity of ceramics. $\mathrm{MnO}_{2}$ does not significantly reduce the annealing temperature, so this additive hasn't any fundamental importance.

\section{Study of the synthesized ceramic element filtering properties}

The experiments were performed on model solutions of mesodispersed saponite clay in distilled or tap water.

A filter element $(25 \mathrm{~mm}$ in diameter and $1.5 \mathrm{~cm}$ in height) was mounted in a glass funnel to obtain purified pressurized water at the level created by human respiration (about $0.01 \mathrm{MPA}$ ).

The following parameters were used to evaluate the filtering efficiency of the ceramic filter element: initial and resultant turbidity of water, which were determined by the nephelometric method; filter rating or pore size by determining the size of the colloidal impurities passing through the filter. 
According to the latter indicator, the pore size of the obtained filter element is greater than $50-55 \mu \mathrm{m}$ (error of determination $+-20 \%$ ).

According to the test results, contaminated water with an output turbidity of $18-30$ NTU was purified to $0.13-1.33$ NTU, which completely meets the requirements of World Health Organisation (2017), since it is considered that the achieved turbidity of water does not contain dangerous pathogens (E-coli - 4-8 microns, Criptosporidium - 2-6 microns, etc.). It is worth noting that better performance was obtained at the beginning of use, worse at the end when pores were clogged with dirt particles. After regeneration (mechanical washing, sanding the surface), its resource was restored.

During the work, samples of filter ceramic elements were also obtained by analogy to the technology mentioned above based on the use of waste diatomite in beer production. A mixture contained $50 \%$ diatomite, $40 \%$ kaolin and $10 \%$ calcium carbonate. The level of turbidity reduction in this case is higher $-0.88-0.91 \mathrm{NTU}$, but there is a lower element performance (average thickness $90-100 \mathrm{~mm}$ ) and a greater pressure drop. The studies were carried out at a pressure of $0.1-1 \mathrm{bar}$.

According to the literature (Erdem, 2005, Salih, 2018) diatomite is a sorbent. In the studies of synthesized ceramics, the parameters for the reduction of water hardness, total salt content and change in $\mathrm{pH}$ were checked. However, no significant adsorption and ion exchange properties were found.

\section{Conclusions}

The use of diatomite-kaolin ceramic filters to reduce water turbidity in small individual water systems in the field without chemical regeneration is justified, since such filters provide a sufficiently high level of turbidity reduction at low pressures.

However, ceramic filtration membrane should not be used as a single purification step, since they do not provide removal of tiny particles of viruses and toxic chemical compounds. Thus, it may be necessary to include disinfection as an additional purification step. For waters that are saturated with heavy metal ions and organic matter, additional purification on activated carbon and ion exchange resins should be provided.

\section{References}

Application brief: TG/DTA Measurements of manganese dioxide. Hitachi high-tech science corporation. 1983.

Breck, D. W. Zeolite molecular sieves: structure, chemistry and use. Malabar, Florida, Krieger, 1984 Erdem, E., Çölgeçen, G., \& Donat, R. The removal of textile dyes by diatomite earth. Journal of Colloid and Interface Science. 2005. 282(2), 314-319. doi: 10.1016/j.jcis.2004.08.166.

Ibrahim S.-A., Selim, Q. (2012). Heat Treatment of Natural Diatomite. Fizykochemiczne Problemy Mineralurgii - Physicochemical Problems of Mineral Processing. 2012, 48, 413-424. doi: 10.5277/ppmp120208.

Kayvani F., Mckay A., Buekenhoudt G., Sulaiti A., Motmans H., Khraisheh F., Atieh M.. Inorganic Membranes: Preparation and Application for Water Treatment and Desalination. Materials 2018, 11(1), 74. doi: 10.3390/ma11010074.

Li K., Preparation of ceramic membranes. Ceramic Membranes for Separation and Reaction, NJ, USA : John Wiley \& Sons, Ltd.: Hoboken, 2007.

Mogollón-Cuellar Z., Silva-Rivero Y., Peña-Rodríguez G. Water Treatment Using Porous Ceramics Based on Recycled Diatomite and Kaolin. Contemporary Engineering Sciences 2018, 11 (75), 3729 - 3738. doi: 10.12988/ces.2018.88366.

Patent US 8,607,992 B2. P. Farrelly, S. McCormack, R. Verkerk, D. Maybin, Ceramic filter. 2008 Qiu Ch., Yang J., Ge Sh., Chang R., Xiong L., Sun Q. Preparation and characterization of sizecontrolled starch nanoparticles based on short linear chains from debranched waxy corn starch. Food Science and Technology. 2016, 74. doi:10.1016/j.lwt.2016.07.062. 
Salih, S. S., Ghosh, T. K. Adsorption of Zn (II) ions by chitosan coated diatomaceous earth. International journal of biological macromolecules. 2018. 106, 602-610. doi: 10.1016/j.ijbiomac.2017.08.053.

Šaponjić A., Stanković M., Majstorović J., Matović B., Ilić S., Egelja A., Kokunešoski M. Porous ceramic monoliths based on diatomite. Ceramics International. 2015, 41(8), 9745-9752. doi: 10.1016/j.ceramint.2015.04.046.

Shiotsubo, T., Takahashi, K. Differential thermal analysis of potato starch gelatinization. Agricultural and Biological Chemistry, 2012, 48(1), 9-17. doi: 10.5277/ppmp120208.

World Health Organization. Water quality and health-review of turbidity: information for regulators and water suppliers (No. WHO/FWC/WSH/17.01). World Health Organization. 2017.

Received 22.11.2019

Revised 25.02.2020

Accepted 18.03.2020

\title{
КЕРАМІЧНІ МЕМБРАНИ В ІНДИВІДУАЛЬНІЙ ПОЛЬОВІЙ ВОДОПІДГОТОВЦІ
}

\author{
А. В. Кузьмінчук*, І. М. Астрелін, Г. В. Кримець \\ НТУУ «Київський політехнічний інститут ім. І. Сікорського», Київ, Україна \\ * e-mail: kuzminchuk.a@gmail.com
}

В статті розглянуто ситуацію, щзо склалася в світовому масштабі з розробкою та використанням фільтрувальної кераміки призначеної для прочесів водопідготовки та водоочищення. Зроблено наголос на потребі залучати до одержання такої кераміки на основі вітчизняної сировинної бази і на виготовленні відповідних фільтроелементів індивідуального використання для водоочищення в польових умовах, зокрема в зоні проведення військових операцій. Викладено власні методики і результати досліджень з синтезу фільтрувальної кераміки на основі природних мінералів (діатоміту, каоліну) в тому числі $і$ з украӥнських родовищ та проаналізовано призначення $i$ вплив різноманітних добавок до первинних сировинних сумішей в процесах термообробки $i$ держання кінцевого керамічного фільтроелемента належної якості - порозності (мікро- та нанорозмірності), механічної міцності. Показники ефективності керамічного фільтроелементу в прочесах водоочищення виявлені при дослідженні зменшення мутності природних забруднених вод та імітантів останніх. Досягнуто зниження мутності з 18-30 NTU до 0,13 - 1, 33 NTU, щуо задовольняє вимоги ВООЗ до якості очищення мутних вод. Проаналізовано ситуацію з використанням синтезованого фільтроелементу у випадку забруднення вод іонами важких металів $i$ дрібними частинками вірусів.

Ключові слова: діатоміт, каолін, термічний аналіз, керамічні мембрани, очищення води.

\section{КЕРАМИЧЕСКИЕ МЕМБРАНЫ В ИНДИВИДУАЛЬНОЙ ПОЛЕВОЙ ВОДОПОДГОТОВКЕ}

\author{
А. В. Кузьминчук*, И. М. Астрелин, Г. В. Кримец \\ НТУУ «Киевский политехнический институт имени Игоря Сикорского», Киев, Украина \\ * e-mail: kuzminchuk.a@gmail.com
}

В статье рассмотрено производство фильтроэлементов индивидуального использования. Изложень методики и результаты исследований по синтезу фильтровальной керамики и проанализировано влияние различных добавок к сырьевым смесям.

Ключевые слова: кизельгур, диатомит, каолин, термический анализ, керамические мембраны, водоподготовка. 